\title{
INTEGRATING STANDARD MARINE COMMUNICATION PHRASES INTO MARITIME ENGLISH COURSE
}

Training of future seafarers for outcome-based professional communication on board a ship is a mandatory condition for their successful career at sea. That is why maritime English teachers and lecturers shall focus on the development and application of teaching and learning materials aimed at formation of cadets'/students' skills in professional communication.

In their everyday life future seafarers are engaged in daily routine communication on an external level between ship and shore, ship and other ships. Moreover, they take part in routine communication on an intraship level between the crewmembers.

Taking into account the multinational and international nature of modern maritime industry, many of the maritime accidents are caused by communication barriers. The diversity in crew and shore personnel engaged in the maritime business may naturally result in communication problems and failures. Moreover, inefficient communication together with differences in English accents of seafarers may cause accidents which may affect human life and marine environment. Standard Marine Communication Phrases were developed and adopted by the International Maritime Organization in order to minimize the risks associated with misunderstanding at sea.

The article studies certain ways of integration of Standard Marine Communication Phrases into maritime English course. The author points out that the learning of Standard Marine Communication Phrases should be carried out systematically and consistently. Besides, it is necessary to develop a thematically oriented and methodically grounded system of exercises and activities, to determine the sequence of their application.

The research proved that the learning of Standard Marine Communication Phrases should be organized on the basis of real-life professional situations and provided through the application of appropriate methods of language learning.

The author of the article discusses the advantages of certain types of exercises and activities, studies the communicative skills required by the IMO Model Course 3.17 "Maritime English" in order to outline the strategy of learning of Standard Marine Communication Phrases. In addition to controlled and semicontrolled exercises, maritime English teachers and lecturers are advised to use simulation and role plays based on real-life professional situations. The results of the analysis will be presented in this article. The research showed that students' competency in Standard Marine Communication Phrases proves applied orientation, operational effectiveness and motivation in performing various exercises and activities.

Key words: maritime English, Standard Marine Communication Phrases, multinational crew, real-life situations, communicative competence.

Problem statement. One of the main goals of modern maritime education is to implement safer navigation worldwide in clean seas, which coincides with the motto of International Maritime Organization (IMO). Standard Marine Communication Phrases (SMCP) can serve as a determinant medium to reach this goal. Nowadays it is officially recommended that every seafarer should have SMCP competency regardless of his position, nationality and area of work. As there is no defined SMPC course in curriculum of maritime institutions, they are integrated logically into the course of Maritime English. Besides, they are supposed to be learnt by cadets/students during the course. As a result, SMCP can be presented with different purposes - training grammar or vocabulary patterns. The author of the article discusses the advantages/disadvantages of activities focused on learning of SMCP, studies the communicative skills required by the IMO Model Course 3.17 in order to outline a choice of activities for Maritime English lessons. The results of the analysis will be presented in this article.

Recent research and publications. The problems of effective maritime communication between crewmembers, the needs and challenges of SMCP use by seafarers have been studied by P. Björkroth, P. John, V. Kudryavtseva, A. Noble, B. Pritchard, A. Şihmantepe, P. Trenkner and many others.

Most of their research papers are devoted to the study of main features of conversation in maritime VHF communication and the standards of training future seafarers in the use of SMCP. Some authors share their own experience of developing such activities that can assist in SMCP training in maritime institutions $[1 ; 5 ; 6 ; 7 ; 8]$. 
The purpose of the research is to carry out an analysis of different activities which can serve as means of training future seafarers for successful on-board communication.

The main text. First of all, it is very important to mention the fact that under the International Convention on Standards of Training, Certification and Watchkeeping for Seafarers (STCW), 1978, as amended, the ability to understand and use SMCP is required for the certification of officers in charge of a navigational watch on ships of 500 gross tonnage or above [4]. SMCP include phrases which have been developed to cover the most important safety-related fields of verbal shore-to-ship (and viceversa), ship-to-ship and on-board communications.

Communicative features of SMCP can be summarized as follows:

- avoiding synonyms;

- avoiding contracted forms;

- providing fully worded answers to yes/no questions and basic alternative answers to sentence questions;

- providing one phrase for one event;

- structuring the corresponding phrases after the principle: identical invariable plus variable [3, p. 2-3].

According to M. Özenir, a lecturer of Istanbul Technical University, getting competency in SMCP is rather complicated for most cadets whereas the use of SMCP is considered to be one of the main requirements to seafarers. He suggests to integrate SMCP into maritime English course as a tool that can consolidate both vocabulary and grammar knowledge. For instance, he recommends to attach grammar patterns with SMCP. The main stress is on the activities used to develop grammar accuracy (a correct use of prepositions, basic modals and tenses, passive voice) [5].

Since SMCP cover and provide guidelines on routine and emergency on-board procedures, it is not enough to focus on accurate use of SMCP patterns only. It is essential that every seafarer is competent in the use of SMCP as he/she is ready for challenges facing modern multinational shipping industry [8].

As the situations which require the use of SMCP (shore-to-ship, ship-to-ship and on-board communications) are numerous, the author has decided to analyze the detailed syllabus of the IMO Model course 3.17 "Maritime English" [2] in order to outline the appropriate topics and skills which can be used for integration of SMCP into Maritime English course. The part "Specialized Maritime English for officers in charge of navigational watch" (table 1) was under analysis.
Table 1

\section{Detailed teaching syllabus of \\ "Specialized Maritime English for officers in charge of navigational watch" (adapted to the research needs)}

\begin{tabular}{|l|l|}
\hline 1.2. How to Use IMO & - simulate distress \\
Standard Marine & communications with given \\
Communication Phrases & standard phrases under different \\
(SMCP) & scenarios such as search \\
1 General & and rescue communications, man \\
2. External & overboard, requesting medical \\
communication phrases & assistance; \\
& - simulate pilotage communication \\
& with given standard phrases \\
& for pilot request, embarking/ \\
& disembarking pilot, tug assistance. \\
\hline 3. On-board & $\begin{array}{l}\text { simulate the communication with } \\
\text { communication phrases } \\
\text { operative shiphandling phrases } \\
\\
\text { under different scenarios such as } \\
\text { entering/leaving port, dropping } \\
\text { anchor, handover of watchkeeping } \\
\text { responsibility. }\end{array}$ \\
\hline
\end{tabular}

The instructor manual of IMO Model Course 3.17 [2] provides Maritime English teachers with more than 25 different activities focused on accuracy and fluency of use of SMCP. All of them can be grouped into certain categories:

1) SMCP drilling (choral drills, split class drills, back chaining drills, individual drills, open and closed pair drills, contrasting drills, substitutional drills, drilling SMCP with cassette);

2) surveys (class survey, group questionnaires);

3) dialogues (vanishing dialogue, half dialogues, guided dialogues, collaborative dialogues, SMCP dialogue prompts);

4) dictations (wall dictations, split pair dictation, "thinking" dictation, student-led dictation, pair race dictation);

5) simulation and role-play (checklist simulation, guided SMCP role-plays, free SMCP role-plays);

6) others (transferring messages to SMCP, students' recordings, random choice communications, SMCP comprehension activities, taking notes, SMCP message markers).

However, among a long list of activities from the IMO Model Course only some of them are really effective (based on a teaching experience). The following sequence of SMCP training is recommended: SMCP drilling - Mini-dialogues - Simulation and Role-plays.

For instance, the series of activities (minimum 5 activities) can be used to learn one set of SMCP. The teacher may start with traditional choral drilling and follow with substitutional drills (controlled activities).

Choral drills: the teacher may use this traditional type of drill focusing on the main requirement that all students repeat a model together. The model is either spoken by the teacher or played 
by a recorder. It is very important to keep a good, quick pace and not to let the drills last for too long. If too much choral drilling is done, students' concentration is likely to lapse. The teacher is advised to demonstrate the same, clear signal each time he/ she wants the group to respond (a verbal command or a physical gesture) and check that everyone in the group is active in speaking [2].

Substitutional drills: when the students have had enough practice with the original SMCP pattern, the teacher is recommended to give them some more varied practice by replacing a word or part of the SMCP pattern with an alternative. Ask the students to suggest their own alternative word or choose an appropriate one from a substitution table [2].

Then the teacher can continue with semi-controlled activities (e. g. half dialogues, SMCP dialogue prompts).

Half dialogues: delete one person's part of a dialogue containing SMCP and give it to the students. Ask them to work in pairs to complete the dialogue using appropriate SMCP phrases. After checking their variants, they should play the dialogue together. Besides, the teacher can adapt this exercise by recording one half of the dialogue on to disc and asking the students to complete the dialogue [2].

SMCP dialogue prompts: the teacher selects some short dialogues containing SMCP that the students are familiar with. Write a prompt in the form of just one or two words for each line of dialogue on the board. Divide the students into pairs and ask them to reconstruct the dialogue without consulting their textbooks or copybooks. The students in pairs should compare their answers and discuss any changes in content. The students should be encouraged to learn the dialogues and to act them out in pairs or small groups in the class [2].

At the final stage, the productive activities must be applied by the teacher (e. g. checklist simulation, guided SMCP role-plays, free SMCP role plays). As future seafarers have to deal with a great number of checklists in their professional life (the checklists are usually used to monitor all routine and emergency procedures on board), the following activity is highly recommended.

Checklist simulation: the teacher prepares an authentic checklist (an appropriate checklist can be photocopied from "Bridge Procedures Guide"). First, drill new vocabulary with the group/class then divide your students into pairs and set up a simple simulation based on information presented in the checklist. For instance, Student A could choose which of the actions/operations in the checklist he/she has completed and which still remain to be done. Student $B$ then asks the partner to find out how much he/she has achieved. The students get an intensive practice of the Present Perfect and Past Simple tenses in the context of checking actions/operations in the checklist that has been done to date. The teacher may extend this simulation into a simple written or oral report at the end of the exchange [2].

The suggested sequence of activities in SMCP training is aimed at linking maritime English classroom and real seafarer's life. The above recommended activities can serve as a regular part of maritime English course, thus integrating SMCP as an important component into its content.

Conclusions. The main goal of learning SMCP within a course of maritime English is to make the environment of maritime English classroom closer to that of a ship's and suggest some professional scenarios of maritime on-board communication in multinational crews. The cadets/students are expected to use the learnt SMCP during their academic training (nautical sciences, simulators) and apply them in real-life situations (routine and emergency procedures).

As for the further research, the author will continue to study this problem. The opportunities of improving SMCP competency of future seafarers through simulator training and life-like scenarios will be under analysis.

\section{References:}

1. Frolova O.O. Interdisciplinary Integration in Teaching Maritime English. Педагогічний альманах. 2017. Вип. 33. С. 210-215.

2. IMO Model Course 3.17. Maritime English. London : International Maritime Organization (IMO), 2010. $138 \mathrm{p}$.

3. IMO Standard Marine Communication Phrases. London: IMO Publishing, 2002. 116 p.

4. International Convention on Standards of Training, Certification and Watchkeeping for Seafarers 1978, as amended in 1995 and 1997 (STCW Convention). London : International Maritime Organization (IMO), 2001. $346 \mathrm{p}$.

5. Özenir M. Integrating SMCP competency into Maritime English curriculum. Proceedings of IMEC-30. 2018. P. 1-7.

6. Şihmantepe A., Beşikçi E.B., Özsever E. Efficiency of IMO SMCP for safe navigation at sea: needs and challenges. Молодий вчений. 2019. Вип. 7.2(71.2). С. 25-29.

7. Кудрявцева В.Ф., Швецова І.В. Стандартні фрази для спілкування на морі як навчальна потреба. Педагогічні науки. 2019. Вип. LXXXVIII. C. 104-109.

8. Frolova O.O., Voloshchuk Ya.Yu., Matiieva K.V. Simulation and role-play as a link between classroom and seafarer's life. Молодий вчений. 2019. Вип. 7.2(71.2). С. 95-98. 


\section{Фролова О. О. Інтеграція стандартних фрраз для спілкування на морі в курс морської англійської мови}

Підготовка майбутніх моряків до ефективної професійної комунікації на судні є обов'язковою умовою успішної кар'єри на морі. Саме тому викладачі морських закладів освіти мають зосередитися на розробленні та використанні навчально-методичних матеріалів, що спрямовані на оволодіння курсантами/студентами навичками профресійної комунікації.

Майбутні моряки у своїй повсякденній діяльності повинні підтримувати зовнішній зв'язок між судном і берегом, між судном та іншими суднами. Крім того, вони беруть участь у внутрішньосудновій комунікації між членами екіпажу.

Беручи до уваги мультинаціональний і міжнародний характер сучасної морської індустрії, багато морських аварійних ситуацій спричинені саме комунікаційними бар'єрами. Окрім цього, невдале спілкування разом із національними відмінностями у використанні моряками англійської мови можуть призводити до аварійних ситуацій, які негативно впливають на людське життя та морське середовище. Саме тому стандартні фррази для спілкування на морі були розроблені й затверджені Міжнародною морською організацією з метою мінімізації випадків непорозуміння.

У статті окреслено певні шляхи інтеграції стандартних фрраз для спілкування на морі в курс морської англійської мови. Автор стверджує, що вивчення визначених стандартних фраз має здійснюватися системно й послідовно. Це зумовлює необхідність розроблення тематично зорієнтованої та методично обгрунтованої системи вправ, а також визначення послідовності їх виконання.

Дослідження показало, що вивчення курсантами/студентами стандартних фраз для спілкування на морі доцільно здійснювати на основі реальних професійних ситуацій і шляхом використання відповідних сучасних методів навчання мови.

Автор статmі розглядає переваги різних типів вправ, вивчає комунікативні навички, зазначені в модельному курсі IMO 3.17 «Морська англійська мова», з метою визначення орієнтовної стратегії вивчення стандартних фрраз. Окрім вправ контрольованого й частково контрольованого характеру, викладачам морської англійської мови варто використовувати також імітаційні та рольові ігри, які мають бути розроблені на основі реальних професійних ситуацій. Представлені у статті результати аналізу свідчать про те, що вивчення курсантами/студентами стандартних фрраз для спілкування на морі доводить прикладну спрямованість, оперативну результативність та вмотивованість курсантів/студентів виконувати такі завдання.

Ключові слова: морська англійська мова, стандартні фрази для спілкування на морі, мультинаціональний екіпаж, ситуації реального життя, комунікативна компетенція. 